\begin{tabular}{|l|l|l||}
\hline \multicolumn{2}{|c|}{ PublisherInfo } \\
\hline \hline PublisherName & $:$ & BioMed Central \\
\hline \hline PublisherLocation & $:$ & London \\
\hline \hline PublisherImprintName & $:$ & BioMed Central \\
\hline \hline
\end{tabular}

\title{
OSM-induced periosteal bone apposition
}

\begin{tabular}{|l|l|l||}
\hline \multicolumn{2}{|c||}{ ArticleInfo } \\
\hline \hline ArticleID & $:$ & 259 \\
\hline \hline ArticleDOI & $:$ & $10.1186 /$ ar-2002-77300 \\
\hline \hline ArticleCitationID & $:$ & 77300 \\
\hline \hline ArticleSequenceNumber & $:$ & 12 \\
\hline \hline ArticleCategory & $:$ & Paper Report \\
\hline \hline ArticleFirstPage & $:$ & 1 \\
\hline \hline ArticleLastPage & $:$ & 3 \\
\hline \hline & & RegistrationDate $: 2002-6-27$ \\
ArticleHistory & $:$ & Received \\
& & Accepted $2002-6-27$ \\
& $:$ & $2002-8-15$ \\
\hline \hline ArticleCopyright & $:$ & Biomed Central Ltd2002 \\
\hline \hline ArticleGrants & $:$ & \\
\hline \hline
\end{tabular}




\begin{tabular}{|l|l|l||}
\hline ArticleContext & $:$ & 130754411 \\
\hline
\end{tabular}

Riako Masuda, ${ }^{\text {Affl }}$

Aff1 University Hospital Zurich, Switzerland

\section{Keywords}

Bone apposition, interleukin-6, Oncostatin M, RANK, RANKL

\section{Context}

Oncostatin M (OSM) is a member of the interleukin (IL)-6 family and induces the expression of IL-6. Since the level of OSM is elevated in the synovial fluid, but not in the serum, in RA, OSM is considered to play a role in the local inflammation seen in RA. To elucidate the influence of OSM on joint inflammation, the authors induced inflammation in wild-type and IL-6 deficient mice using an injection of adenoviral vector expressing murine OSM (AdmuOSM).

\section{Significant findings}

In spite of OSM inducing the expression of IL-6, histological scoring of joint inflammation showed no difference between wild-type and IL-6 deficient mice. Moreover, periosteal bone apposition (the formation of layers of osteoblast-like cells and the deposition of new bone) occurred in the injected joints of both strains. These results suggest that these effects of OSM are not mediated by IL-6. Using murine osteoblast cell lines, the authors showed that new formation of bone is caused by the interaction of OSM with other bone-forming factors such as BMP-2. At sites of bone apposition, RANK (receptor activator of nuclear factor- $\mathrm{kB}$ ) and RANKL (RANK ligand) were also expressed but no osteoclasts could be detected. In addition, the authors that showed overexpression of OSM induced the expression of RANKL inhibitor osteoprotegerin (OPG), which might control bone resorption.

\section{Comments}


Since OSM is an inducer of IL-6, its effects on inflammation have been considered to be dependent on IL-6. In this study, the authors showed the effects of OSM were independent of IL-6 by using IL-6 deficient mice. Moreover, the most characteristic feature which occurred on overexpression of AdmuOSM was periosteal bone apposition. Because bone resorption rather than periosteal bone apposition is frequently seen in RA, the inflammation induced by AdmuOSM does not perfectly reflect the pathogenesis of RA. As the authors discussed, periosteal bone apposition is seen in other diseases, such as juvenile chronic arthritis and erosive osteoarthritis: further analysis of the role of OSM in these diseases might be helpful for their therapy. Furthermore, it is interesting that there were no osteoclastlike cells at the site of bone apposition in spite of the expression of RANKL and RANK. The authors speculated RANKL-RANK pathway was inhibited by OPG whose expression was induced by the overexpression of AdmuOSM. Although OSM stimulation has previously been reported to play a role in osteoclast differentiation, the results of this paper suggest that OSM inhibits osteoclast differentiation and might control bone resorption in inflammatory joints.

\section{Methods}

Adenoviral transfer, ALP, ALP assay, IL-6 deficient mice, immunohistochemistry, semiquantitative RT-PCR, TRAP, Von Kossa and Goldner's Trichrome staining.

\section{References}

1. de Hooge ASK, van de Loo FAJ, Bennink MB, de Jong DS, Arntz OJ, Lubberts E, Richards CD, van den Berg WB: Adenoviral transfer of murine Oncostatin M elicits periosteal bone apposition in knee joints of mice, despite synovial inflammation and up-regulated expression of interleukin-6 and receptor activator of nuclear factor- $\mathrm{KB}$ ligand. Am J Pathol . 2002, 160: 1733-1743.

This PDF file was created after publication. 